\title{
STRATEGI PENGEMBANGAN PEGAWAI DI DINAS PENDIDIKAN KABUPATEN BANTUL DAN DINAS PENDIDIKAN KABUPATEN SLEMAN
}

\author{
1)Fifit Firmadani, 2)Wiwik Wijayanti \\ 1)Fakultas Keguruan dan Ilmu Pendidikan Universitas Tidar Magelang \\ 2)Fakultas Ilmu Pendidikan Universitas Negeri Yogyakarta \\ 1)fifitfirmadani@yahoo.co.id, 2)wiwikwijayanti@uny.ac.id
}

\begin{abstract}
Abstrak
Penelitian ini bertujuan untuk mendeskripsikan proses need assessment dalam pengembangan pegawai dan strategi pengembangan pegawai yang dilakukan di Dinas Pendidikan Kabupaten Bantul dan Dinas Pendidikan, Pemuda, dan Olahraga Kabupaten Sleman. Penelitian ini menggunakan pendekatan kualitatif dengan jenis penelitian fenomenologi. Informan utama dalam penelitian ini adalah kepala dinas, kepala sub bagian kepegawaian, dan staf. Teknik pengumpulan data menggunakan teknik wawancara dan analisis dokumentasi. Teknik analisis data menggunakan model interaktif Miles \& Huberman, yang meliputi pengumpulan data, reduksi data, penyajian data, dan penarikan kesimpulan.Hasil penelitian menunjukkan bahwa pengembangan pegawai baik di Dinas Pendidikan Kabupaten Bantul dan Dinas Pendidikan Pemuda, dan Olahraga Kabupaten Sleman tidak terlepas dari peran Badan Kepegawaian Daerah (BKD): (1) proses need assessment dilakukan secara top down dan bottom up, dengan menggunakan tiga analisis yaitu analisis organisasi, analisis tugas, dan analisis individu dan (2) strategi pengembangan pegawai yang dilakukan baik di Dinas Pendidikan Kabupaten Bantul dan Dinas Pendidikan Pemuda, dan Olahraga Kabupaten Sleman meliputi pendidikan dan pelatihan yang dapat berupa bimbingan teknis, workshop, tugas belajar, dan izin belajar; promosi atau kenaikan pangkat; mutasi atau perpindahan jabatan; dan pembinaan.
\end{abstract}

Kata kunci: need assessment, strategi pengembangan pegawai

\section{THE EMPLOYEE DEVELOPMENT STRATEGY OF EDUCATION DEPARTMENT OF BANTUL DISTRICT AND EDUCATION DEPARTMENT OF SLEMAN DISTRICT}

\author{
1)Fifit Firmadani, 2)Wiwik Wijayanti \\ 1)Fakultas Keguruan dan Ilmu Pendidikan Universitas Tidar Magelang \\ 2)Fakultas Ilmu Pendidikan Universitas Negeri Yogyakarta \\ 1)fifitfirmadani@yahoo.co.id, 2)wiwikwijayanti@uny.ac.id
}

\begin{abstract}
This study aims to know the process of need assessment in the employee development and the employee development strategy which was applied in Education Department of Bantul District and Education, Youth, and Sport Department of Sleman District. The study carried out through a qualitative phenomenological approach. The key informants of this study were the head of department, the head of the sub-section of personnel, and the staff. The techniques of data collecting were in-depth interview and document review. The data analysis technique applied was related to Miles $\mathcal{E}$ Huberman interactive model whose major phases were data collection, data reduction, data display, and conclusion. The results show that the employee development in Education Department of Bantul District and Education, Youth and Sport Department of Sleman District was influenced by Local Employment Agency (BKD): (1) need assessment process is done through top down and bottom up by applying three kinds of analysis, namely organisation analysis, tasks analysis, and individual analysis and (2) employee development strategy done in both Education Office of Bantul District and Education, Youth, and Sport Department of Sleman District includes education and training such as technique guidance (bimtek), workshop, study assignment, study permission, job promotion, job assignment, job transfer, and choaching.
\end{abstract}

Keywords: need assessment, employee development strategy 


\section{Pendahuluan}

Organisasi merupakan sekelompok orang yang saling bekerjasama satu sama lain untuk mencapai tujuan organisasi yang dirumuskan. Sekelompok orang tersebut biasa disebut pegawai atau karyawan. Mereka mempunyai keterampilan dan keahlian yang berbeda-beda. Penyatuan keterampilan dan keahlian itulah yang dapat mendorong pencapaian tujuan organisasi. Organisasi tidak dapat lepas dari peran pegawai atau karyawan yang merupakan sumber daya untuk menjalankan program kerja organisasi.

Sumber daya manusia sangat penting bagi sebuah organisasi publik maupun organisasi nonpublik. Organisasi tersebut mempunyai tujuan yang hendak dicapai. Tujuan organisasi akan dapat diwujudkan apabila setiap organisasi mendayagunakan dan memberdayakan segenap sumber daya manusia yang dimiliki, karena untuk mencapai tujuan organisasi diperlukan sumber daya manusia (pegawai) yang sesuai dengan persyaratan dalam organisasi. Mereka juga harus mampu menjalankan tugastugas yang telah ditentukan oleh instansi dan organisasi. Oleh karena itu, suatu organisasi harus memiliki sumber daya yang profesional.

Terkait dengan hal tersebut, masih banyak kekhawatiran dalam bidang kesiapan sumber daya manusia. Menurut Anwar (2004, p.1) "kekhawatiran muncul karena dalam menyiapkan diri menghadapi persaingan dan tuntutan profesionalisme di segala bidang masih jauh dari harapan." Dalam mempersiapkan diri para pegawai atau karyawan, perlu adanya peningkatan kinerja. Peningkatan kinerja diadakan dengan tujuan agar sumber daya manusia yang dimiliki suatu organisasi dapat menjadi berkompeten dan profesional. Sumber daya yang berkompeten dan profesional akan dapat mendukung tercapainya tujuan organisasi.

Kemampuan pegawai tercermin dari kinerja, kinerja yang baik adalah kinerja yang optimal. Kinerja pegawai merupakan salah satu modal bagi organisasi dalam rangka mencapai tujuan. Kinerja pegawai merupakan hasil kerja yang dicapai seseorang dalam melaksanakan tugas-tugas yang dibebankan kepadanya untuk mencapai target kerja sesuai dengan bidang tugasnya. Pegawai dapat bekerja dengan baik apabila dia memiliki kinerja yang tinggi. Kinerja yang tinggi akan mempengaruhi produktivitas dari organisasi. Oleh karena itu, kinerja dari para pegawai perlu mendapatkan perhatian.

Kaitannya dengan organisasi publik, UU RI Nomor 43 Tahun 1999 tentang Perubahan Pokok-Pokok Kepegawaian Nomor 8 Tahun 1974 menyatakan bahwa "manajemen sumber daya aparatur negara (PNS) diarahkan untuk menjamin penyelenggaraan tugas pemerintahan dan pembangunan secara berdayaguna dan berhasil guna." Untuk mewujudkan hal tersebut, diperlukan Pegawai Negeri Sipil (PNS) yang profesional, bertanggung jawab, jujur, adil. Salah satu upaya melalui pembinaan dan sistem karier yang dititikberatkan pada sistem prestasi kerja. Pembinaan dan sistem karier diharapkan dapat dirasakan oleh seluruh pegawai yang ada di organisasi. Upaya tersebut dapat dilakukan secara berkala atau sesuai dengan program yang dirumuskan, halnya demikian dengan di Dinas Pendidikan

Dinas Pendidikan memiliki fungsi yang sangat strategis dalam mengelola penyelenggaraan sistem pendidikan, sehingga tercipta penyelenggaraan pendidikan di daerah yang berhasil guna dan berdaya guna. Sehubungan dengan hal tersebut, Dinas Pendidikan dituntut untuk melaksanakan manajemen sumber daya manusia yang baik. Pelaksanaan manajemen sumber daya manusia yang baik dapat meningkatkan kualitas kerja pegawai. Kualitas kerja pegawai yang baik akan berdampak pada pelayanan yang diberikan kepada publik, terutama dalam kantor dinas pendidikan.

Dinas Pendidikan khususnya yang ada di Provinsi Daerah Istimewa Yogyakarta merupakan lembaga yang mempunyai tugas dan wewenang kegiatan di dalam bidang pendidikan, generasi pemuda, dan olahraga yang diberikan pemerintah. Terkait dengan tugas dan wewenangnya, 
maka perlu dilakukan pengembangan agar dapat mewujudkan pendidikan yang berhasil dan berdaya guna dan mampu mempersiapkan generasi muda yang mempunyai kemampuan akademik maupun nonakademik. Dengan demikian, menuntut untuk mempunyai para pegawai yang profesional dalam melaksanakan tugas sesuai dengan job description di dalam kantor Dinas Pendidikan. Hal tersebut dapat dilakukan dengan cara meningkatkan kinerja melalui pengembangan pegawai dan penyediaan fasilitas yang memadai untuk menunjang tugas mereka sehingga proses pelayanan dapat berjalan dengan lancar secara efektif dan efisien.

Berdasarkan studi pendahuluan yang telah dilakukan pada bulan Oktober 2014 di Dinas Pendidikan Kabupaten Bantul dan Dinas Pendidikan, Pemuda, dan Olahraga Kabupaten Sleman, pelaksanaan pengembangan pegawai sudah sesuai dengan bidang tugasnya masing-masing, tetapi masih terdapat beberapa kendala.

Kendala tersebut antara lain Dinas Pendidikan Kabupaten Bantul dan Dinas Pendidikan Pemuda, dan Olahraga Kabupaten Sleman tidak memiliki kewenangan dalam pengembangan pegawai untuk meningkatkan kompetensi pegawai yang ada di Dinas Pendidikan, karena kewenangan pengembangan pegawai berada di Badan Kepegawaian Daerah (BKD). Hal tersebut menjadikan Dinas Pendidikan Kabupaten Bantul dan Dinas Pendidikan Pemuda, dan Olahraga Kabupaten Sleman tidak dapat menyelenggarakan kegiatan pengembangan pegawai sesuai dengan kebutuhan Dinas. Kendala yang lain adalah pegawai Dinas Pendidikan Kabupaten Bantul dan Dinas Pendidikan Pemuda dan Olahraga Kabupaten Sleman masih memiliki motivasi yang kurang dalam mengikuti kegiatan pengembangan pegawai untuk meningkatkan kompetensinya. Pegawai Dinas Pendidikan Kabupaten Bantul dan Dinas Pendidikan Pemuda, dan Olahraga Kabupaten Sleman belum sepenuhnya memiliki inisiatif untuk mengusulkan keikutsertaan mereka dalam kegiatan pengembangan pegawai khususnya pendidikan dan pelatihan.
Penelitian ini memfokuskan pada proses need assessment dan strategi pengembangan pegawai di Dinas Pendidikan Kabupaten Bantul, dan Dinas Pendidikan, Pemuda, dan Olahraga Kabupaten Sleman.

Penelitian ini diharapkan dapat dapat menambah pengetahuan tentang pengembangan sumber daya manusia terkait dengan proses need assessment dan strategi pengembangan pegawai yang dilakukan. Manfaat lain yang diperoleh dalam hasil penelitian ini diharapkan dapat memberikan informasi bagi Dinas Pendidikan Kabupaten Bantul dan Dinas Pendidikan, Pemuda, dan Olahraga Kabupaten Sleman dalam upaya kebijakan pelaksanaan pengembangan pegawai agar dapat meningkatkan kinerja dengan optimal dan masukan bagi Dinas Pendidikan Kabupaten Bantul dan Dinas Pendidikan, Pemuda, dan Olahraga Kabupaten Sleman dan untuk dijadikan pertimbangan kontekstual dan konseptual operasional dalam merumuskan pola peningkatan kinerja pegawai secara optimal.

Pengembangan pegawai adalah suatu usaha yang penting dalam organisasi karena dengan pengembangan inilah organisasi akan dapat maju dan berkembang melalui pengetahuan dan keterampilan yang dimiliki oleh para pegawai. Pegawai yang bermutu adalah mereka yang mempunyai kecakapan dan kemampuan untuk menyelesaikan suatu pekerjaan yang dibebankan kepadanya, dapat memelihara dan meningkatkan kecakapan dan kemampuannya itu secara teratur dan pasti serta akan menjadi bekal untuk beradaptasi dengan perubahan. Organisasi sangat mendambakan adanya pegawai yang demikian, oleh karena itu dengan berbagai cara dan usaha pengembangan pegawai terus dilakukan. Kemajuan keterampilan pegawai akan mengakibatkan peningkatan produktivitas bagi mereka dan organisasi karena memberikan hasil kerja yang memuaskan.

\section{Metode Penelitian}

Penelitian ini menggunakan pendekatan kualitatif dengan jenis penelitian 
fenomenologi. Penelitian ini dilaksanakan pada bulan Desember 2014 sampai dengan Februari 2015. Tempat yang digunakan dalam penelitian ini adalah di Dinas Pendidikan Dasar Kabupaten Bantul, Dinas Pendidikan Menengah dan Non-Formal Kabupaten Bantul, dan Dinas Pendidikan Pemuda, dan Olahraga Kabupaten Sleman.

Dalam menentukan sumber data dilakukan dengan menggunakan metode purposive sampling dan snowball sampling. Menurut Sugiyono (2012, pp.53-54) metode purposive sampling merupakan metode pengambilan sampel yang didasarkan atas pertimbangan peneliti terhadap narasumber mana yang memiliki pengetahuan baik atas masalah yang diteliti, terkait penelitian ini adalah masalah proses need assessment dan strategi pengembangan pegawai di Dinas Pendidikan Dasar Kabupaten Bantul, Dinas Pendidikan Menengah dan Non-Formal Kabupaten Bantul dan Dinas Pendidikan Pemuda, dan Olahraga Kabupaten Sleman. Sedangkan teknik snowball sampling adalah pengambilan sampel sumber data, yang pada awalnya jumlahnya sedikit, kemudian menjadi banyak menyesuaikan kebutuhan atas data. Hal ini dilakukan dengan mendapatkan informan baru melalui narasumber yang telah diwawancara sebelumnya.

Subyek penelitian di sini selanjutnya disebut dengan key informant. Informan dalam penelitian kualitatif berkaitan dengan bagaimana langkah yang ditempuh oleh peneliti agar data informasi diperoleh (Bungin, 2011, p. 107). Dalam penelitian ini, peneliti menentukan informan utama (key informant) yang dimintai keterangan mengenai proses need assessment dan strategi pengembangan pegawai. Key informant di masing-masing lokasi penelitian berjumlah empat orang yang terdiri dari: Kepala Dinas, Sekretaris Dinas, Kepala Sub Bagian Kepegawaian, Staf. Sementara informan sekunder dalam penelitian ini berjumlah lima orang yang terdiri dari Kepala Sub Bidang Penyelenggaraan Pendidikan dan Pelatihan BKD Kabupaten Bantul, Kepala Sub Bidang Promosi dan Mutasi BKD Kabupaten Bantul, Kepala Sub Bidang Penye- lenggaraan Pendidikan dan Pelatihan BKD Kabupaten Sleman, Kepala Sub Bidang Pengembangan Pegawai BKD Kabupaten Sleman, Kepala Bidang Mutasi BKD Kabupaten Sleman. Semua sumber data dalam penelitian ini bertambah karena konteks dan bervariasinya informan dari responden yang dapat mendukung data yang dibutuhkan oleh peneliti. Dalam konteks inilah, penggunaan teknik snowball sampling digunakan untuk mencari informan tambahan baik dari key informant maupun informan sekunder.

Staf yang dijadikan sumber data dalam penelitian ini tidak diklasifikasikan berdasarkan tingkat usia, masa kerja, pangkat/golongan, akan tetapi dalam penelitian ini, penulis memberikan batasan yaitu pegawai fungsional umum yang pernah mengikuti atau melaksanakan kegiatan pengembangan pegawai. Para staf juga dijadikan salah satu key informant dalam penelitian ini. Adapun dalam menentukan sampel staf yang menjadi key informant dalam penelitian ini, peneliti menggunakan teknik snowball sampling, yaitu dengan cara mencari informasi dari staf satu kepada staf yang lain untuk menentukan narasumber yang diwawancara selanjutnya. Jumlah staf di ketiga lokasi penelitian masing-masing berjumlah lima orang. Jumlah keseluruhan responden dalam penelitian ini berjumlah 32 responden, karena dengan jumlah tersebut, peneliti sudah mendapatkan keajegan informasi mengenai masalah yang diteliti.

Teknik pengumpulan data yang digunakan dalam metode kualitatif ini meliputi wawancara mendalam (indepth interview) dan analisis dokumentasi.

Wawancara yang dilakukan dalam penelitian ini adalah wawancara secara mendalam (indepth interview) yang bertujuan untuk menggali informasi terkait dengan proses need assessment dan strategi pengembangan pegawai yang ada di Dinas Pendidikan Dasar Kabupaten Bantul, Dinas Pendidikan Menengah dan Non-Formal Kabupaten Bantul, dan Dinas Pendidikan Pemuda dan Olahraga Kabupaten Sleman. Jenis wawancara dalam penelitian ini 
adalah wawancara semistruktur (semistructure interview). Wawancara jenis ini memudahkan peneliti untuk menggali informasi karena lebih bebas untuk dilakukan.

Analisis dokumen digunakan untuk memperoleh informasi yang bersifat tertulis (data sekunder) berkaitan dengan kebijakan dan program-program pengembangan pegawai, hasil dari pengembangan pegawai yang terdokumentasikan di Dinas Pendidikan Dasar Kabupaten Bantul, Dinas Pendidikan Menengah dan Non-Formal Kabupaten Bantul, dan Dinas Pendidikan, Pemuda, dan Olahraga Kabupaten Sleman. Analisis dokumen dilakukan dengan penelaahan terhadap dokumen Analisis Kebutuhan Diklat (AKD), data pegawai yang mengikuti pengembangan pegawai, keputusan-keputusan, peraturan daerah, peraturan perundang-undangan. Proses analisis dokumen didukung dengan pedoman dokumentasi dan flash disk khusus untuk menyimpan dokumen dalam bentuk soft copy yang akan dianalisis.

Instrumen Instrumen yang digunakan dalam penelitian ini adalah peneliti itu sendiri yaitu pada saat permasalahan belum jelas dan pasti, maka yang menjadi instrumen adalah peneliti sendiri. Tetapi setelah masalah yang telah dipelajari jelas, maka dikembangkan suatu instrumen. Instrumen yang dikembangkan adalah pedoman wawancara. Pedoman wawancara yang dibuat adalah pedoman wawancara mendalam (indepth interview). Pengabsahan data dalam penelitian ini dilakukan dengan cara kredibilitas, dependabilitas, dan konfirmabilitas.

Teknik analisis data yang dilakukan dalam penelitian ini mengadopsi teknik analisis Miles \& Huberman (1994, p.10) yang terdiri dari beberapa langkah yaitu meliputi pengumpulan data, reduksi data, penyajian data, dan penarikan kesimpulan.

\section{Hasil Penelitian dan Pembahasan}

Hasil penelitian mengenai strategi pengembangan pegawai terdiri dari dua pokok bahasan utama yaitu meliputi proses need assessment (penilaian kebutuhan) dan strategi pengembangan yang dilakukan.

Proses Need Assessment (Penilaian Kebutuhan)

Terkait dengan pengembangan pegawai di Dinas Pendidikan Kabupaten Bantul dan Dinas Pendidikan Pemuda dan Olahraga Kabupaten Sleman melakukan need assessment terlebih dahulu. Tujuan dari need assessment yang dilakukan adalah untuk mengetahui kesenjangan kebutuhan pegawai baik dilihat dari kebutuhan kompetensi, pengetahuan, dan keterampilan yang harus dimiliki maupun jumlah pegawai yang dibutuhkan.

Proses need assessment yang ada di Dinas Pendidikan Kabupaten Bantul sama dengan yang dilakukan di Dinas Pendidikan Pemuda, dan Olahraga Kabupaten Sleman yaitu dilakukan secara top down dan bottom up. Proses need assessment secara top down, atasan langsung yaitu Kepala Dinas, Kepala Bagian, maupun Kepala Sub Bagian yang melihat kebutuhan dinas maupun pegawai meliputi kompetensi, pengetahuan, keterampilan, dan jumlah pegawai yang diperlukan serta melihat kesenjangan volume pekerjaan dengan jumlah pegawai yang dimiliki. Proses need assessment secara bottom up dilakukan dengan adanya usulan kebutuhan pengembangan pegawai dari bidang atau unit yang ada di Dinas Pendidikan Kabupaten Bantul dan Dinas Pendidikan Pemuda, dan Olahraga Kabupaten Sleman.

Proses need assessment yang dilakukan di ketiga lokasi penelitian dilakukan dengan cara kuesioner dan pengamatan. Kuesioner dilakukan untuk mengetahui apa saja kebutuhan yang diperlukan oleh setiap bidang atau unit yang ada di Dinas baik kebutuhan pegawai terkait dengan kebutuhan pengetahuan, kompetensi, dan keterampilan maupun kebutuhan tambahan pegawai karena volume pekerjaan yang over. Pembagian kuesioner dibagikan setiap awal tahun. Kuesioner tersebut dibagikan ke setiap bidang/unit untuk diisi oleh Kepala Bidang maupun Kepala Sub Bagian 
kemudian direkapitulasi oleh Bagian Kepegawaian.

Terkait dengan proses need assessment secara bottom up, baik di Dinas Pendidikan Kabupaten Bantul dan Dinas Pendidikan Pemuda, dan Olahraga Kabupaten Sleman, staf belum melakukan pengusulan secara mandiri untuk mengikuti kegiatan pengembangan berupa pelatihan, bimtek, maupun workshop karena volume pekerjaan yang sudah banyak dan merasa keterampilan yang dimiliki sudah cukup untuk menyelesaikan pekerjaan yang menjadi tanggung jawabnya. Mereka lebih sering ditugaskan oleh atasan langsung dalam hal ini kepala dinas, kepala bidang atau kepala sub bagian, selain itu nama staf yang akan mengikuti pelatihan, bimtek, maupun workshop sudah ditentukan oleh pihak penyelenggara. Sedangkan kegiatan pengembangan seperti studi lanjut yang bersifat izin belajar, staf mengusulkan sendiri kepada kepala dinas dan disampaikan ke Badan Kepegawaian Daerah yang bertujuan untuk peningkatan kualifikasi pendidikan mereka.

Proses need assessment yang dilakukan melalui pengamatan dilakukan oleh atasan langsung dalam hal ini bisa Kepala Dinas, Kepala Bidang, Kepala Seksi, dan Kepala Sub Bagian terhadap keadaan yang ada di lingkungan dinas dan bidang/unitnya. Aspek yang diamati adalah hasil kerja yang diberikan oleh para pegawainya, kesenjangan jumlah pegawai dengan volume pekerjaan yang ada, tuntutan perubahan lingkungan yang terjadi.

Hasil dari form dan pengamatan kebutuhan nantinya akan disampaikan kepada Badan Kepegawaian Daerah (BKD) karena pada dasarnya ketiga lokasi penelitian hanya memiliki wewenang untuk mengusulkan sedangkan untuk tindak lanjutnya sudah menjadi wewenang oleh Badan Kepegawaian Daerah (BKD) di masing-masing kabupaten dimana lokasi penelitian berada.

Proses need assessment yang ada baik di Dinas Pendidikan Kabupaten Bantul dan Dinas Pendidikan Pemuda, dan Olahraga
Kabupaten Sleman dilakukan dengan melakukan tiga analisis yaitu:

\section{Analisis Organisasi}

Dalam proses need assessment, Dinas Pendidikan Kabupaten Bantul dan Dinas Pendidikan Pemuda, dan Olahraga Kabupaten Sleman melakukan analisis organisasi, analisis ini mengidentifikasi kebutuhan organisasi terkait dengan pengembangan pegawai secara keseluruhan. Dinas Pendidikan Kabupaten Bantul dan Dinas Pendidikan Pemuda, dan Olahraga Kabupaten Sleman mengacu kepada misinya agar dapat memberikan pelayanan yang baik terhadap masyarakat, sehingga pegawai harus mempunyai kompetensi, pengetahuan, dan keterampilan sesuai dengan job description yang dimiliki, disesuaikan dengan SPM, serta pelaksanaan tugas, peran, dan fungsi sesuai yang tercantum dengan Undang-Undang No 5 tahun 2014 tentang Aparatur Sipil Negara.

Analisis Tugas

Mengacu pada analisis tugas, Dinas Pendidikan Kabupaten Bantul maupun Dinas Pendidikan Pemuda, dan Olahraga Kabupaten Sleman menentukan kebutuhan pengembangan pegawai. Dari hasil analisis tugas atau jabatan akan diketahui kompetensi, pengetahuan, dan keterampilan yang harus dimiliki pegawai sehingga akan diketahui spesifikasi pengembangan yang akan dilakukan. Armstrong (1994, p.211) menjelaskan bahwa pengembangan yang dipilih menetapkan karakteristik hal yang harus dimiliki oleh pekerja untuk melaksanakan tugas-tugas agar berhasil. Karakteristik yang diperlukan adalah: ilmu pengetahuan, keterampilan, dan perilaku.

Karakteristik tersebut sudah di tetapkan oleh ketiga lokasi penelitian. Ketiga lokasi penelitian menetapkan ilmu pengetahuan, keterampilan, dan perilaku yang diperlukan oleh para pegawai disesuaikan dengan bidang tugasnya masing-masing agar hasil kerja yang dicapai dapat sesuai dengan harapan atau standar yang ditetapkan dan dapat memberikan pelayanan yang memuaskan kepada masyarakat karena 
ketiga lokasi penelitian tersebut merupakan pelayan masyarakat dalam bidang pendidikan.

\section{Analisis Individu}

Atasan langsung dalam hal ini Kepala Dinas, Kepala Bidang, maupun Kepala Sub Bagian yang ada di Dinas Pendidikan Kabupaten Bantul maupun Dinas Pendidikan Pemuda, dan Olahraga Kabupaten Sleman menganalisis kebutuhan pengembangan dengan melihat hasil kerja yang diberikan oleh para pegawainya. Hasil kerja tersebut disesuaikan dengan job description yang dimiliki untuk mengetahui apakah masih terdapat kesenjangan antara hasil kerja/produk dengan job description, selain itu juga disesuaikan pada Standar Pelayanan Minimal (SPM), UndangUndang No 5 Tahun 2014 tentang Aparatur Sipil Negara (ASN) juga dijadikan pedoman dalam melakukan proses need assessment, dimana pegawai yang ada di Dinas Pendidikan harus mampu memiliki tugas, fungsi, dan perannya sesuai dengan Undang-Undang tersebut.

Cara pendekatan tersebut juga seperti yang diungkapkan oleh Armstrong (1994, p. 211), ketika analisis lebih jauh mengenai individu atau kelompok-kelompok dari pekerja adalah untuk bisa mengetahui dari apa yang dapat kita harapkan dari mereka lakukan, cara pendekatannya yaitu didasarkan pada hasil-hasil yang dibandingkan dengan sasaran-sasaran yang telah ditetapkan atau patokan prestasi kerja untuk setiap jenis pekerjaan. Jika hasil tidak mencapai patokan yang ditetapkan, maka manajer dan bawahan bekerjasama untuk menganalisis mengapa hal ini terjadi. Tetapi, jika suatu kesalahan yang timbul dianggap berasal dari pihak pekerja maka perlu diadakan suatu diskusi untuk menetapkan apa yang harus dilakukan dan bila diperlukan bantuan, adakan pengarahan.

Analisis yang digunakan oleh Dinas Pendidikan Kabupaten Bantul dan Dinas Pendidikan, Pemuda, dan Olahraga Kabupaten Sleman bertujuan untuk melihat kesenjangan antara yang diharapkan dengan yang ada secara real, mulai dari melihat kesenjangan keseluruhan dari apa yang dimiliki oleh organisasi, mengacu kepada visi misi, tujuan jangka pendek dan panjang, struktur organisasi, budaya dan iklim kerja (Gomez-Meija, 2003, p. 285), untuk mewujudkan aspek-aspek tersebut maka diperlukan para pegawai yang mempunyai kompetensi, pengetahuan, dan keterampilan yang sesuai serta jumlah pegawai yang memadai agar dapat melaksanakan pekerjaan di dalam organisasi dalam rangka mewujudkan visi misi dan tujuan jangka pendek-panjang serta budaya dan iklim kerja yang kondusif.

Selain melakukan analisis organisasi, Dinas melakukan analisis tugas yaitu analisis jabatan, hal ini mengacu kepada struktur organisasi yang dimiliki bahwa hasil dari analisis jabatan akan diketahui kompetensi, pengetahuan, dan keterampilan yang sesuai untuk menduduki jabatan tersebut. Armstrong (2006, p. 181) menjelaskan bahwa analisis jabatan merupakan proses pencarian dari apa yang orang harapkan untuk mencapai ketika menjalankan pekerjaan mereka serta kompetensi dan keterampilan yang mereka butuhkan untuk harapan tersebut. Jadi, suatu proses pencarian yang dilakukan oleh pimpinan untuk menentukan kriteria seseorang/pegawai yang sesuai dengan keterampilan dan kompetensi yang dimiliki pada bidang yang diharapkan (the right man in the right place), hal tersebut juga yang diharapkan oleh Dinas Pendidikan Kabupaten Bantul dan Dinas Pendidikan Pemuda, dan Olahraga Kabupaten Sleman, bahwa pegawai yang menduduki jabatan tertentu harus mempunyai kompetensi, pengetahuan, dan keterampilan sesuai dengan jabatan tersebut, yang pada akhirnya akan menentukan kegiatan pengembangan pegawai yang sesuai dengan kebutuhan.

Analisis kebutuhan pengembangan pegawai yang dilakukan selain analisis organisasi dan tugas, Dinas Pendidikan Kabupaten Bantul dan Dinas Pendidikan Pemuda, dan Olahraga Kabupaten Sleman melakukan analisis individu yaitu dengan melihat hasil kerja/produk yang diberikan 
disesuaikan dengan standar, di Dinas yang dijadikan standar adalah job description yang dimiliki pegawai, Standar Pelayanan Minimal (SPM), dan Undang-Undang No 5 Tahun 2014 tentang Aparatur Sipil Negara dimana di dalam Undang-Undang tersebut mencantumkan tugas, peran, dan fungsi seorang Pegawai Negeri Sipil (PNS) atau Aparatur Sipil Negara (ASN). Apabila pegawai belum memenuhi standar tersebut maka Dinas mendelegasikan untuk melaksanakan kegiatan pengembangan yang sesuai.

Ketiga analisis kebutuhan pengembangan apabila digambarkan adalah sebagai berikut.

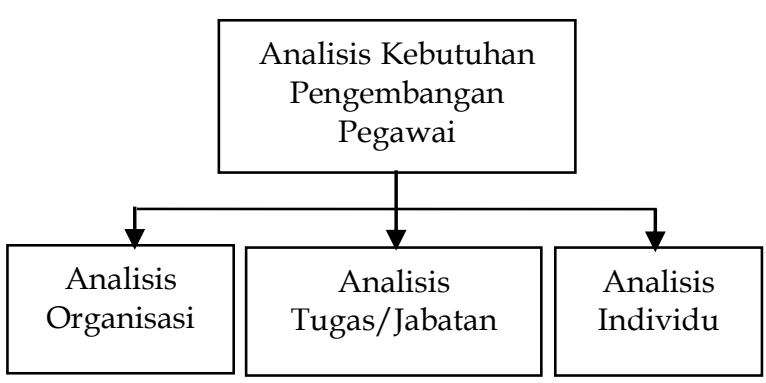

Gambar 1. Analisis Kebutuhan

Pengembangan Pegawai

Strategi Pengembangan Pegawai

Pengembangan pegawai (baru/lama) perlu dilakukan secara terencana dan berkesinambungan. Agar pengembangan dapat dilaksanakan dengan baik, harus lebih dahulu ditetapkan suatu program program pengembangan pegawai. Menurut Hasibuan (2007, p.68) bahwa pengembangan harus bertujuan untuk meningkatkan kemampuan teknis, teoretis, konseptual, dan moral pegawai supaya prestasi kerjanya baik dan mencapai hasil yang optimal.

Strategi pengembangan pegawai yang dilakukan di Dinas Pendidikan Dasar Kabupaten Bantul dan Dinas Pendidikan Menengah dan Non-Formal Kabupaten Bantul dan Dinas Pendidikan Pemuda dan Olahraga Kabupaten Sleman tidak terlepas dari peran Badan Kepegawaian Daerah (BKD) di masing-masing Kabupaten.

Strategi pengembangan pegawai yang dilakukan di Dinas Pendidikan Dasar Kabupaten Bantul dan Dinas Pendidikan
Menengah dan Non-Formal Kabupaten Bantul sama dengan strategi pengembangan pegawai yang dilakukan di Dinas Pendidikan Pemuda, dan Olahraga Kabupaten Sleman, yaitu meliputi:

\section{Pendidikan dan Pelatihan}

Pendidikan dan Pelatihan (diklat) yang dilaksanakan di Dinas pendidikan Kabupaten Bantul dan Dinas Pendidikan Pemuda, dan Olahraga Kabupaten Sleman bertujuan untuk meningkatkan kompetensi, pengetahuan, dan keterampilan yang dimiliki para pegawai agar dapat sesuai dengan tuntutan job descriptionnya di dalam dinas sehingga menunjang dan memperlancar tugas-tugas kedinasannya. Para pegawai yang diberikan kesempatan untuk pemberdayaannya melalui pendidikan dan pelatihan akan bisa mendapatkan keuntungan dari kegiatan tersebut, dengan meningkatkan keterampilan proses kerja, semua pegawai dapat membuat lebih baik kinerjanya dengan menggunakan keahlian masing-masing dan menjadi aktif berkomitmen untuk proses peningkatan kualitas (Batool \& Batool, 2012, p.17).

Setiap awal tahun, Dinas Pendidikan Kabupaten Bantul dan Dinas Pendidikan Pemuda, dan Olahraga Kabupaten Sleman menyusun Analisis Kebutuhan Diklat (AKD) yang berisi kebutuhan-kebutuhan diklat yang diperlukan dari bidang-bidang yang ada di Dinas. AKD ini nantinya akan dikumpulkan kepada Bagian Kepegawaian yang ada di Dinas untuk disampaikan kepada Badan Kepegawaian Daerah (BKD) yang ada di masing-masing Kabupaten untuk direkap karena tidak hanya Dinas Pendidikan saja yang mengumpulkan, tetapi juga semua kebutuhan diklat dari Satuan Kerja Perangkat Daerah (SKPD) yang ada, kemudian dianalisis bersama dalam diskusi panel, kebutuhan diklat apa saja yang menjadi skala prioritas dengan melihat kebutuhan dan anggaran sehingga nantinya menentukan plafon anggaran Pemerintah Daerah.

Pendidikan dan Pelatihan (diklat) yang dilakukan di Dinas Pendidikan Kabupaten Bantul dan Dinas Pendidikan Pemu- 
da, dan Olahraga Kabupaten Sleman ditujukan untuk pegawai yang memiliki jabatan struktural dan fungsional. Pendidikan dan Pelatihan (diklat) untuk jabatan struktural yaitu diklat kepemimpinan antara lain PIM II untuk Kepala Dinas, PIM III untuk Sekretaris Dinas dan Kepala Bidang, PIM IV untuk Kepala Seksi dan Kepala Sub Bagian, sedangkan diklat untuk jabatan fungsional yaitu diklat keteknisan.

Pendidikan dan Pelatihan (diklat) juga dapat dilakukan dalam bentuk bimtek atau workshop, dan studi lanjut.

\section{Bimtek atau Workshop}

Bimtek dan workshop yang diikuti disesuaikan dengan tugas pokok dan fungsi atau job description dari pegawai yang akan mengikuti kegiatan tersebut, karena pegawai yang ada di Dinas, baik di Dinas Pendidikan Kabupaten Bantul dan Dinas Pendidikan, Pemuda, dan Olahraga Kabupaten Sleman sudah mempunyai tupoksi dan job descriptionnya masing-masing. Pegawai yang akan mengikuti kegiatan tersebut didelegasikan baik oleh Kepala Dinas, Kepala Bidang, maupun Kepala Sub Bagian sesuai dengan materi kegiatan dari penyelenggara dengan job description yang dimiliki oleh pegawai dan diberikan surat tugas.

Berdasarkan data yang diperoleh, kegiatan diklat, bimtek, dan workshop yang diikuti oleh pegawai Dinas Pendidikan Kabupaten Bantul dan Dinas Pendidikan Pemuda, dan Olahraga Kabupaten Sleman sudah sesuai dengan bidang tugas yang dimiliki oleh pegawai, sehingga hal tersebut dapat menunjang pelaksanaan pekerjaannya di dalam Dinas.

Bentuk penyampaian materi dalam kegiatan diklat, bimtek atau workshop yang diikuti oleh para pegawai yaitu berupa ceramah, diskusi, praktek, coaching clinic atau kolaborasi dari bentuk-bentuk tersebut disesuaikan dengan materi yang diberikan. Seperti yang dijelaskan oleh Dwyer (2004, p.7) bahwa pemilihan metode yang paling tepat tergantung pada karakteristik kelompok tertentu dan sifat pembelajaran yang diharapkan. Metode ceramah, demonstrasi dan pertanyaan, efisien untuk pembelajaran pada peserta yang kurang percaya diri dan belum memiliki pengetahuan mengenai topik pembelajaran yang diberikan. Metode interaktif memanfaatkan komunikasi antar peserta serta antara pelatih dan peserta. Kelompok diskusi, proyek kelompok, dan mengajar antarrekan adalah contoh metode interaktif. Metode individual didasarkan pada asumsi bahwa orang belajar pada tingkat yang berbeda. Ini membutuhkan pelatih untuk memberikan peserta dengan umpan balik langsung dan teratur untuk memfasilitasi proses pembelajaran.

\section{Studi Lanjut}

Studi lanjut yang dilakukan oleh para pegawai Dinas Pendidikan Kabupaten Bantul maupun Dinas Pendidikan Pemuda, dan Olahraga Kabupaten Sleman merupakan pengembangan pegawai melalui pendidikan formal dalam jenjang yang lebih tinggi dari pendidikan formal yang dilakukan sebelumnya, dengan tujuan untuk mengembangkan ilmu dalam rangka ingin melayani sebaik-baiknya kepada masyarakat agar masyarakat dapat terlayani dan menambah pengetahuannya sehingga nantinya diharapkan dapat memperlancar kualitas pekerjaannya di Dinas. Keberhasilan organisasi dalam jangka panjang akan memerlukan pegawai yang memiliki pendidikan tinggi karena mampu mengatasi perubahan lingkungan internal dan eksternal yang cepat. Pendidikan mampu memberikan kegiatan untuk membantu pegawai dalam mencapai peningkatan kompetensi, pengetahuan, dan keterampilan, sehingga hal ini memerlukan dukungan dari organisasi (Romanowska, 1993, p.16).

Pegawai mengikuti tugas belajar atas rekomendasi dari atasan langsung dengan memperhatikan pangkat/golongan, masa kerja, dan hasil kinerja yang dimiliki oleh pegawai yang akan dicalonkan kemudian diusulkan kepada Badan Kepegawaian Daerah (BKD). Anggaran tugas belajar yang diikuti oleh pegawai di Dinas Pendidikan Kabupaten Bantul dan Dinas Pendidikan Pemuda, dan Olahraga Kabupaten Sleman dibebankan pada pihak sponsor yang me- 
nawarkan beasiswa kepada para pegawai, seperti Pemerintah Daerah, Kemendikbud, dan Bappenas. Pegawai yang mendapatkan tugas belajar diberhentikan sementara dari tugas kedinasan dengan tetap diberikan gaji pokok tanpa diberikan tunjangan. Pengambilan konsentrasi bidang studi dalam pelaksanaan tugas belajar ini disesuaikan dengan kebutuhan dari Dinas.

Izin belajar dilakukan atas inisiatif sendiri dari pegawai untuk melanjutkan ke jenjang pendidikan formal yang lebih tinggi. Izin belajar ini dilaksanakan di luar jam kerja. Pengambilan konsentrasi disesuaikan dengan job descripion pegawai di Dinas.

Pendidikan dan pelatihan yang dilakukan baik oleh Dinas Pendidikan Dasar Kabupaten Bantul, Dinas Pendidikan Menengah dan Non-Formal Kabupaten Bantul, dan Dinas Pendidikan Pemuda, dan Olahraga Kabupaten Sleman merupakan metode off the job karena diselenggarakan oleh pihak eksternal seperti BKD, Kemendikbud, DIKPORA DIY, LPPKS, BPSDMPK PMP, Bandiklat Yogyakarta, BKN Yogyakarta, FE dan Bisnis UGM, INIXINDO, KORPRI, Dinas Perkebunan dan Kehutanan Provinsi DIY, Perguruan Tinggi, dan BPKP. Metode off the job yang dilakukan ketiga dinas tersebut meliputi bimtek, workshop, dan studi lanjut ke jenjang yang lebih tinggi melalui pendidikan formal. Hal ini sesuai dengan penjelasan Rebore (2011, p.192) bahwa off-the-job mengacu pada berbagai macam program, seperti kuliah, seminar, lokakarya (workshop), studi kasus, program instruksi, dan simulasi.

\section{Promosi (Kenaikan Pangkat)}

Promosi yang dimaksud dalam penelitian ini adalah kenaikan jabatan. Promosi yang dilakukan di Dinas Pendidikan Kabupaten Bantul dan Dinas Pendidikan Pemuda, dan Olahraga Kabupaten Sleman bertujuan untuk memotivasi pegawai baik langsung maupun secara tidak langsung untuk dapat mengembangkan kompetensi dan kinerjanya dengan harapan dapat dipromosikan di waktu yang akan datang dan sebagai upaya kaderisasi.
Promosi yang ditemukan dalam penelitian ini adalah promosi reguler atau kenaikan reguler yaitu kenaikan yang didasarkan atas pengalaman kerja dalam suatu masa kerja tertentu, melalui syaratsyarat penilaian prestasi kerja, kesetiaan, pengabdian, pengalaman, dan syarat-syarat objektif lain. Nilai untuk tiap komponen agar dapat naik pangkat adalah "Baik", sehingga atasan langsung dalam hal ini bisa Kepala Dinas, Kepala Bidang, atau Kepala Sub Bagian berkewajiban melakukan pembinaan sehingga tahu persis kompetensi pegawainya seperti apa, layak atau tidak dipromosikan nantinya.

Selain harus memenuhi syarat administratif, calon pegawai yang akan dipromosikan juga harus lolos tes psikologi, dimana ada tiga kategori hasil dari tes psikologi yaitu kader potensial, masih dapat dikembangkan, dan perlu dibina, yang dapat dipromosikan adalah kader potensial dan masih dapat dikembangkan. Penilaian tersebut dilakukan oleh assesor, yaitu tim penguji psikologi dari BKD untuk menguji calon pejabat struktural eselon $\mathrm{V}$ dan IV serta LPKM UGM untuk eselon III dan II.

\section{Mutasi (Perpindahan Jabatan)}

Mutasi yang dimaksud dalam penelitian ini adalah perpindahan jabatan baik secara vertikal maupun horizontal. Mutasi yang dilakukan di Dinas Pendidikan Kabupaten Bantul dan Dinas Pendidikan Pemuda, dan Olahraga Kabupaten Sleman bertujuan untuk mengembangkan kompetensi, pengetahuan, maupun keterampilannya di lingkungan kerja yang baru dan memenuhi kebutuhan jumlah pegawai. Mutasi yang ada baik di Dinas Pendidikan Kabupaten Bantul dan Dinas Pendidikan Pemuda, dan Olahraga Kabupaten Sleman adalah mutasi ke dalam dinas dan ke luar dinas.

Mutasi ke dalam dinas berasal dari tenaga yang diambil dari sekolah seperti penjaga sekolah, tenaga Tata Usaha, dan guru, maupun tenaga yang berasal dari UPT PPD Kecamatan. Mutasi ke luar dinas yaitu pegawai dinas dimutasikan ke UPT 
PPD Kecamatan yaitu seperti di UPT PPD Kecamatan Sedayu, Pleret, dan Sewon. Mutasi yang terjadi dikarenakan kekurangan pegawai fungsional dan mengisi kekosongan formasi yang ada. Kekosongan ini terjadi karena ada pegawai yang pensiun sesuai batas usia dan pensiun dini, dipromosikan ke bidang atau instansi lain, meninggal dunia, dan diberhentikan secara tidak hormat. Selain itu, mutasi juga terjadi karena kurang optimalnya kompetensi yang dimiliki di lingkungan kerjanya sehingga dimutasikan ke Dinas agar kompetensi yang dimiliki menjadi optimal, contohnya guru TIK karena pada saat berlakunya Kurikulum 2013, dia tidak mendapatkan jam mengajar sehingga dia mengajukan permohonan ke BKD untuk dimutasikan ke Dinas, hal ini terjadi di Dinas Pendidikan Dasar Kabupaten Bantul.

Dinas maupun personal mengusulkan permohonan untuk dimutasikan dan meminta tambahan tenaga ke Bupati melalui Badan Kepegawaian Daerah (BKD), kemudian atas permohonan tersebut, Badan Kepegawaian Daerah (BKD) juga melakukan analisis kepegawaian berdasar dari database yang dimiliki oleh BKD untuk melihat ketersediaan tenaga dan instansi yang dibutuhkan.

Terkait dengan promosi dan mutasi, kegiatan tersebut melibatkan penugasan pegawai untuk berbagai pekerjaan sehingga mereka memperoleh dasar yang lebih luas tentang keterampilan. Memperluas pengalaman kerja yang dapat memberikan pegawai lebih banyak fleksibilitas untuk memilih jalur karier. Selain itu, sebagaimana dijelaskan oleh Cheraskin \& Campion (1996, p.11), rotasi pekerjaan tidak dapat diabaikan dari kegiatan pengembangan pegawai karena dapat meningkatkan pengetahuan dan keterampilan pegawai. Rotasi pekerjaan dapat meningkatkan tiga keterampilan yaitu teknis, bisnis, dan administratif. Keterampilan teknis meliputi pengetahuan tentang prosedur akuntansi keuangan dan operasi. Keterampilan bisnis meliputi pengetahuan tentang komponen keuangan dan departemen lain yang mendukung pegawai, isu-isu internasional, dan pengetahuan tentang bagaimana organisasi beroperasi. Keterampilan administrasi meliputi perencanaan, komunikasi, interpersonal, kepemimpinan, kognitif, dan komputer. Di sisi karir, ada kepuasan karir, keterlibatan, dan motivasi dalam karir seseorang.

Namun, program rotasi pekerjaan memiliki beberapa kelemahan, rotasi pekerjaan tidak sesuai dengan pegawai yang ingin mempertahankan fokus yang sempit dan khusus. Dari sudut pandang organisasi, mereka dapat memperlambat operasi karena pegawai perlu belajar keterampilan baru. Sementara manfaat pengembangan melalui rotasi pekerjaan mungkin tinggi dalam jangka panjang, organisasi harus menyadari jangka pendek dan biaya menengah. Dari sudut pandang pegawai, kesempatan rotasi pekerjaan mungkin merupakan mekanisme bertahan hidup. Secara khusus, perampingan dalam suatu organisasi dapat berfokus pada menghilangkan bagian yang lama. Ketika pegawai memperluas kemampuan mereka melalui rotasi pekerjaan, mereka membantu memastikan umur panjang dan kegunaannya bagi organisasi (Gomez-Meija, 2001, p.325).

\section{Pembinaan}

Pengembangan pegawai lain yang ditemukan di Dinas Pendidikan Kabupaten Bantul dan Dinas Pendidikan Pemuda, dan Olahraga Kabupaten Sleman adalah pembinaan. Pembinaan yang dimaksud dalam penelitian ini adalah pemberian motivasi, koordinasi, evaluasi tugas, dan penyampaian ilmu-ilmu yang dapat diterapkan dalam tugas kedinasan.

Baik Dinas Pendidikan Kabupaten Bantul maupun Dinas Pendidikan Pemuda, dan Olahraga Kabupaten Sleman melaksanakan kegiatan tersebut dengan memanfaatkan apel pagi yaitu hari Senin sampai dengan Jumat sebelum para pegawai memulai pekerjaannya. Penyampaian materi dilakukan secara bergilir, hari Senin oleh Kepala Dinas, hari Selasa sampai dengan Jumat dilakukan oleh Sekretaris Dinas, Kepala Bidang, maupun Kepala Sub Bagian sesuai dengan jadwalnya. Selain itu, ada 
koordinasi secara internal di setiap bidangbidang yaitu setiap hari Senin yang membahas mengenai permasalahan-permasalahan yang ditemukan dalam tugas, evaluasi pekerjaan, dan penyampaian informasiinformasi, kemudian pada hari Selasa diadakan rapat koordinasi tingkat dinas yaitu antara Kepala Dinas, Kepala Bidang, Kepala Seksi, dan Kepala Sub Bagian membahas permasalahan yang ada di bidang masing-masing bersama pemecahannya.

Pendekatan personal antara atasan langsung dengan pegawainya juga dilakukan dengan memanfaatkan waktu di selasela pekerjaan secara informal yang memberikan motivasi dan membantu pegawainya dalam menyelesaikan tugasnya apabila ada kesulitan, sehingga secara tidak langsung dapat mengembangkan kemampuan pegawai dan juga menciptakan hubungan yang baik antara atasan dengan bawahan. Pembinaan yang tidak formal dilakukan dengan memperlakukan pegawai sebagai mitra pribadi dalam mencapai tujuan pribadi dan organisasi. dengan memecahkan masalah pribadi pegawai dan ketika masalah terselesaikan pegawai dapat meningkatkan kinerja sehingga mampu mencapai tujuan organisasi (Hameed \& Waheed, 2011, p.10).

Hal di atas seperti dijelaskan oleh Gomez-Meija (2001, p.311) bahwa pembinaan pegawai terdiri dari pertemuan yang sedang berlangsung, kadang-kadang spontan, antara pimpinan dan pegawai, mereka untuk mendiskusikan tujuan pengembangan karir pegawai. Banyak pimpinan melihat peran mereka sebagai salah satu pihak yang memberikan jawaban (problem solver) atas masalah yang ditemukan, menunjukkan kelemahan yang dimiliki pegawai, mendiagnosis dan memecahkan masalah.

Pimpinan memiliki tanggung jawab untuk menilai praktek organisasi saat ini dan melakukan perbaikan yang akan menyeimbangkan tujuan perkembangan individu dan organisasi. Ketika pegawai membutuhkan dan mencari bantuan, pimpinan harus dapat memberikan bantuan atau dukungan, sehingga memungkinkan pimpin- an untuk menciptakan dan mempertahankan kepercayaan dialog dengan pegawai agar meningkatkan hubungan mereka. Drake, Meckler, dan Meckler (2002, p.11) menjelaskan bahwa ketekunan dan kepedulian pimpinan sangat berperan untuk memantau prestasi atau perkembangan hasil kerja pegawai.

Pendekatan tersebut telah dilakukan baik di Dinas Pendidikan Kabupaten Bantul dan Dinas Pendidikan Pemuda, dan Olahraga Kabupaten Sleman, dengan adanya kedekatan antara pimpinan dengan pegawai melalui koordinasi interen, tingkat dinas, dan koordinasi informal di dalam suasan kerja, menciptakan iklim kerja yang kondusif karena terciptanya keakraban sehingga secara tidak langsung dapat menjadikan motivasi bagi para pegawai untuk dapat menyelesaikan pekerjaannya dengan lancar dan memberikan hasil atau produk yang baik.

\section{Simpulan dan Saran}

\section{Simpulan}

Berdasarkan hasil penelitian yang dilakukan dapat disimpulkan bahwa perencanaan pengembangan pegawai terkait proses need assessment dilakukan secara top down dan bottom up. Need assessment secara top down, pengambil kebijakan atau atasan langsung dalam hal ini Kepala Dinas, Kepala Bagian dan Kepala Sub Bagian yang mengambil kebijakan untuk pegawai dalam kegiatan pengembangannya. Need assessment secara bottom up, bidang atau unit yang ada di Dinas mengusulkan kepada Kepegawaian yang ada di Dinas atau Kepala Dinas mengenai kebutuhan yang diperlukan di bidang atau unit tersebut.

Dalam proses need assessment, Dinas melakukan analisis secara organisasi, tugas, dan individu. Analisis organisasi, Dinas berpedoman pada visi misi, tujuan jangka pendek dan panjang, serta budaya dan iklim kerja yang dimiliki. Analisis tugas, Dinas melakukan analisis jabatan sehingga diketahui kompetensi, pengetahuan, dan keterampilan yang harus dimiliki oleh pegawai dalam menduduki suatu jabatan. 
Analisis individu, Dinas melihat hasil kerja atau produk yang diberikan oleh pegawai disesuaikan dengan job description-nya, Standar Pelayanan Minimal (SPM) yang dimiliki oleh Dinas, dan pelaksanaan tugas, peran, dan fungsi sesuai yang tercantum dengan Undang-Undang No 5 tahun 2014 tentang Aparatur Sipil Negara.

Pelaksanaan pengembangan tersebut tidak terlepas dari peran Badan Kepegawaian Daerah (BKD) di masing-masing Kabupaten, karena manajemen kepegawaian tingkat daerah berada di BKD sesuai dengan Peraturan Daerah Nomor 17 Tahun 2007. Strategi pengembangan pegawai yang dilakukan baik di Dinas Pendidikan Kabupaten Bantul dan Dinas Pendidikan Pemuda, dan Olahraga Kabupaten Sleman diantaranya (a) pendidikan dan pelatihan (diklat) yang dapat berupa bimtek, workshop, dan studi lanjut, (b) promosi atau kenaikan jabatan, (c) mutasi atau perpindahan jabatan, dan (d) pembinaan.

Implikasi

Penelitian ini dapat memberikan implikasi bahwa pelaksanaan pengembangan pegawai memerlukan kesadaran dari semua pihak baik itu Kepala Dinas, Kepala Bidang, Kepala Sub Bagian, dan Staf karena pengembangan pegawai dapat memberikan penambahan kompetensi, pengetahuan, maupun keterampilan diperoleh dalam kegiatan pengembangan akan menjadi penunjang tugas kedinasan sehingga dapat memperlancar dan meningkatkan kualitas ketugasan yang dihasilkan.

Saran

Berdasarkan hasil penelitian, beberapa saran disampaikan kepada Dinas Pendidikan terkait dengan strategi pengembangan pegawai yaitu: (1) melakukan rekapitulasi secara rutin terkait pegawai yang sudah dan atau belum mengikuti kegiatan pengembangan pegawai khususnya pendidikan dan pelatihan agar data rekapitulasi dapat siap digunakan apabila dibutuhkan; (2) melakukan koordi-nasi yang rutin dengan Badan Kepegawaian Daerah (BKD) terkait dengan formasi yang tersedia se- hingga tidak ada perbedaan dalam perhitungan formasi; (3) memberikan dorongan untuk para pegawai agar lebih berinisiatif untuk mengembangkan kompetensi, pengetahuan, dan keterampilannya.

\section{Daftar Pustaka}

Anwar. (2004). Pendidikan kecakapan hidup. Bandung: Alfabeta

Armstrong, M. (1994). Manajemen sumber daya manusia. Jakarta: Gramedia

Armstrong, M. (2006). A handbook of human resource management practice. London: Kogan Page

Batool, A. \& Batool, B. (2012) Effect of employees training on the organizational competitive advantage: Empirical study of Private Sector of Islamabad, Pakistan. Far East Journal of Psychology and Business Vol. 6 No. 1. Diambil pada tanggal 25 Februari 2015, dari http:/ / www.fareastjournals.com/fi les/fejpbv6n1p5.pdf

Bungin, B. (2011). Penelitian kualitatif: Komunikasi, ekonomi, kebijakan publik, dan ilmu sosial lainnya. Jakarta: Kencana Prenada Media Group

Cheraskin, L., \& Campion, M. A. (1996). Study clarifies job-rotation benefits. Personnel Journal, 75(11), 31-38. Diambil pada tanggal 2 Maret 2015, dari

http:/ / search.proquest.com/ docvie $\mathrm{w} / 219762264$ ? accountid $=3132$

Drake, B. H., Meckler, M., \& Stephens, D. (2002). Transitional ethics: Responsibilities of supervisors for supporting employee development. Journal of Business Ethics, 38(1), 141-155. Diambil pada tanggal 26 Februari 2015, dari http:/ / search.proquest.com/ docvie w/198145596? accountid=31324

Dwyer, R. J. (2004). Employee development using audit education principles. Industrial and Commercial Training, 
36(2), 79-85. Diambil pada tanggal 26 Februari 2015, dari http:/ / search.proquest.com/docvie $\mathrm{w} / 214108721$ ?accountid=31324

Gomez-Meija, L.R., Balkin, D.B. \& Cardy, R.L. (2001). Managing human resources. New Jersey: Prentice hall, Inc

Hameed, A \& Waheed, A. (2011). Employee development and its affect on employee performance a conceptual framework. International Journal of Business and Social Science Vol 2 No 13. Diambil pada tanggal 27 Februari 2015 dari http://www.ijbssnet.com/journals /Vol._2_No._13_Special_Issue_July _2011/26.pdf

Hasibuan, S. P.M. (2007). Manajemen sumber daya manusia. Jakarta: Bumi Aksara
Miles, M.B., \& Huberman, A.M. (1994). An expanded sourcebook qualitative data analysis. Thousand Oaks: SAGE Publications

Rebore, R. W. (2011). Human resources administration in education: A management approach. New Jersey: Pearson

Republik Indonesia. (1999). Undang-Undang RI Nomor 43, Tahun 1999, tentang Perubahan Pokok-Pokok Kepegawaian Nomor 8 Tahun 1974

Romanowska, J. (1993). Employee development through education liaison. Journal Education \& Training, 35(3), 3. Diambil pada tanggal 3 Februari 2015, dari http:/ / search.proquest.com/docvie $\mathrm{w} / 237073439$ ?accountid $=31324$

Sugiyono. (2012). Memahami penelitian kualitatif. Bandung Alfabeta 